\title{
Estimation of Surface Subsidence at the Waste Isolation Pilot Plant
}

Craig A. Givens, Miguel A. Valdivia, and Saeid Saeb

International Technology Corporation, Albuquerque, New Mexico, USA

Christopher T. Francke and Stanley J. Patchet

Waste Isolation Division, Westinghouse Electric Corporation, Carlsbad, New Mexico, USA

\begin{abstract}
Subsidence effects at the WIPP site were estimated using numerical methods as well as the influence function method and NCB method because a single universally accepted method is not available for salt. The use of parallel methods and the agreement between their results greatly enhanced the confidence in the analysis because the prediction would not depend on the assumptions inherent in a single method.
\end{abstract}

\section{RÉSUMÉ}

Les effets d'affaissement a site WIPP etaient estimés en utilisant les méthodes numériques et aussi avec la méthode de fonction d'influence et la méthode de NCB. Ceci est à cause de non-existence d'une seule méthode acceptable universale pour le sel. L'utilisation des méthodes en paralleles et l'accord entre leurs resultats augmentent la confidence des resultats obtenue parceque la prediction ne dépend pas sur les suppositions inherentes d'une seule méthode.

\section{DISCLAIMER}

This report was prepared as an account of work sponsored by an agency of the United States Government. Neither the United States Government nor any agency thereof, nor any of their employees, makes any warranty, express or implied, or assumes any legal liability or responsibility for the accuracy, completeness, or usefulness of any information, apparatus, product, or process disclosed, or represents that its use would not infringe privately owned rights. Reference herein to any specific commercial product, process, or service by trade name, trademark, manufacturer, or otherwise does not necessarily constitute or imply its endorsement, recommendation, or favoring by the United States Government or any agency thereof. The views and opinions of authors expressed herein do not necessarily state or reflect those of the United States Government or any agency thereof. 


\section{DISCLAIMER}

Portions of this document may be illegible in electronic image products. Images are produced from the best available original document. 


\section{INTRODUCTION}

The Waste Isolation Pilot Plant (WIPP) is located in southeastern New Mexico about fifty kilometers east of Carlsbad. The United States Congress authorized WIPP in 1979 (Public Law 96-164) to provide "... a research and development facility to demonstrate the safe disposal of radioactive wastes resulting from the defense activities and programs of the United States..." The WIPP intends to receive, handle, and permanently dispose of transuranic (TRU) waste. To fulfill this mission, the U.S. Department of Energy is constructing a full scale facility to demonstrate both technical and operational principles of the permanent isolation of TRU waste.

The underground facility consists of (1) the main shaft area and associated access drifts; (2) a waste emplacement area to the south of the main shaft area that consists of eight panels of seven rooms each to be used for the disposal of TRU radioactive waste (only Panel 1 is presently excavated); and (3) an experimental area for non-radioactive experiments developed to the north of the main shaft area. Figure 1 presents a schematic view of the underground facilities at the WIPP site.
This paper investigates various computer and noncomputer methods for predicting surface subsidence over the WIPP underground facility. It also compares the results of these methods to assess the level of confidence for applying these methods in bedded evaporite deposits.

\section{GEOLOGY AND STRATIGRAPHY}

The underground facility at the WIPP is located approximately 650 meters $(\mathrm{m})$ below the surface in bedded salt of the Permian Salado Formation of southeast New Mexico. Figure 2 shows the generalized stratigraphy of the WIPP facility. Over $300 \mathrm{~m}$ of impermeable evaporite deposits separate the facility horizon from overlying sedimentary formations, and $600 \mathrm{~m}$ of evaporites lie below the facility horizon and provide a barrier against underlying Permian limestones and sandstones.

The facility horizon lies within an evaporite sequence consisting of halite, argillaceous halite, and polyhalite. Observations indicate that these beds are laterally continuous.

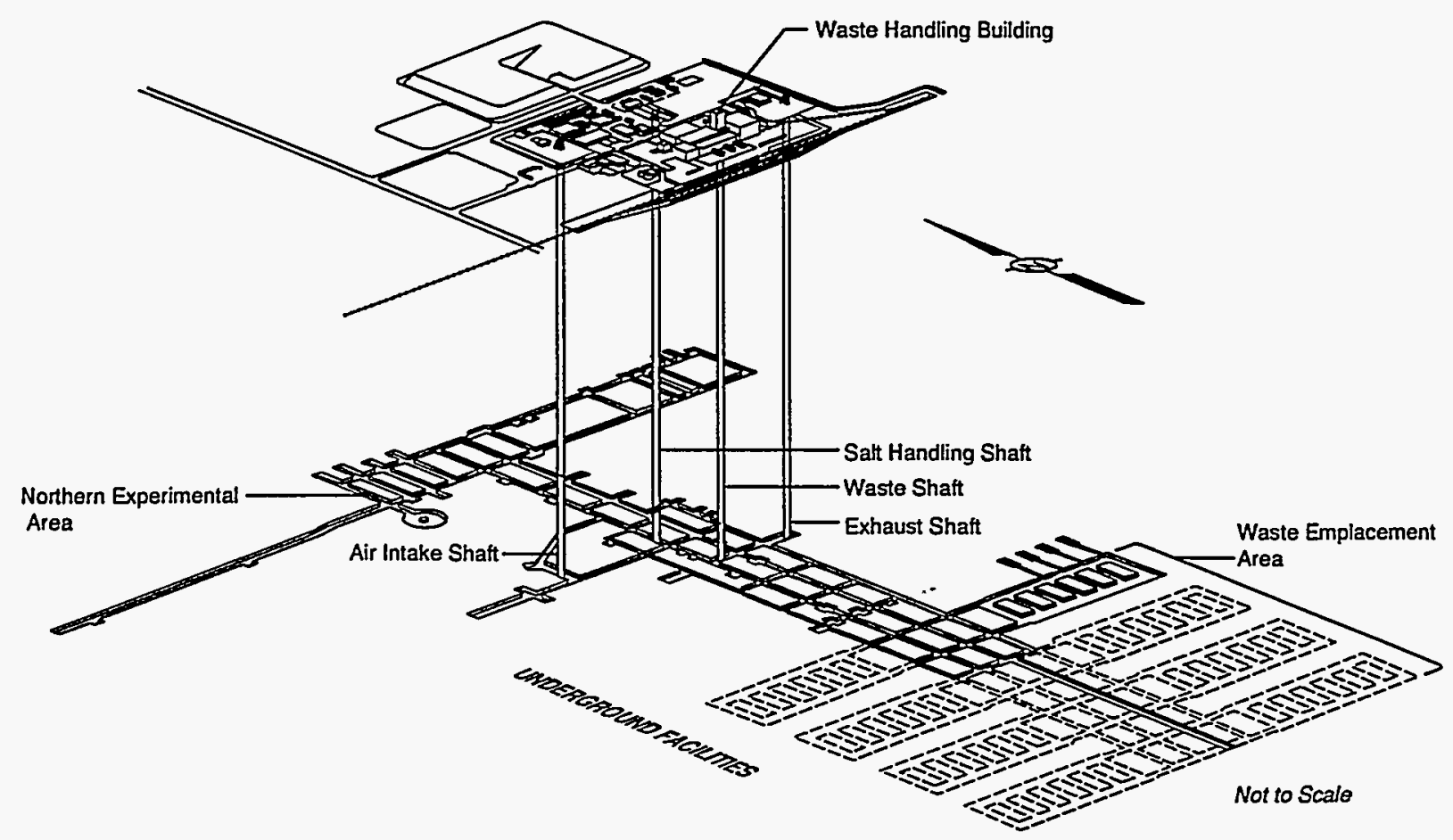

Figure 1

Surface and Underground Layout of the WIPP Facility 


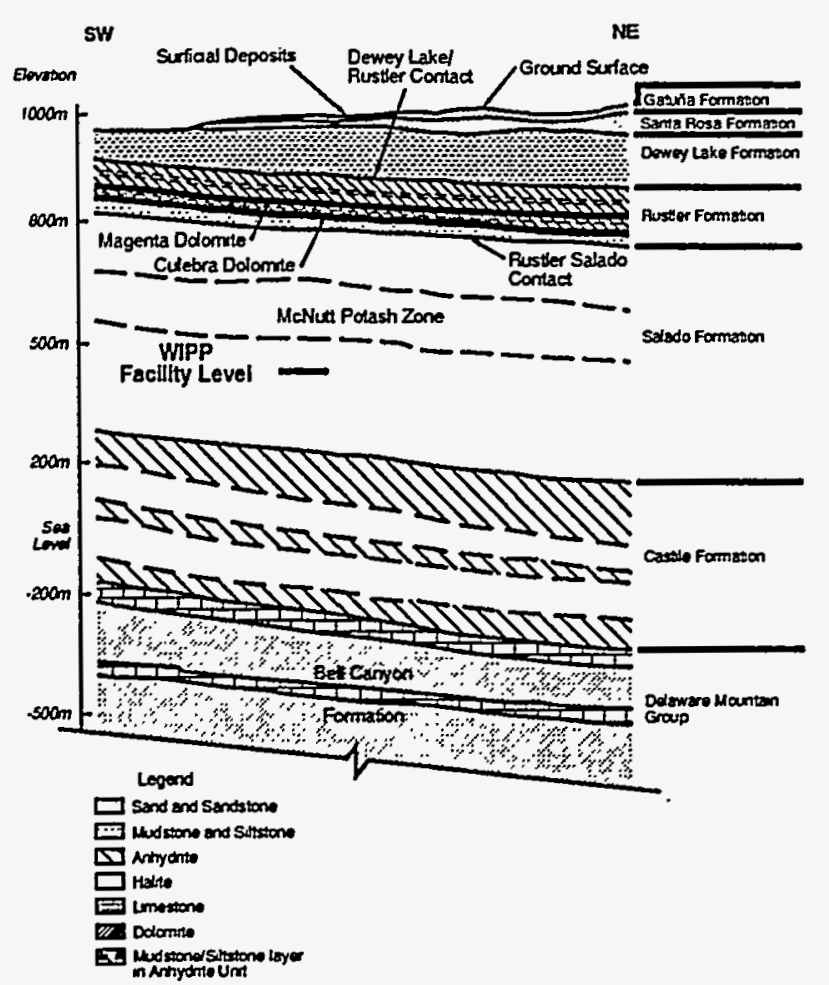

Figure 2

Generalized Stratigraphic Cross Section of the WIPP Site

After excavation of an opening, stresses in the surrounding rock redistribute. In rock salt, the excavation responds initially by elastic deformation due to stress redistribution, and subsequently by inelastic, time-dependent deformation due to deviatoric stresses. As a result of this time-dependent behavior, known as creep, the surrounding rock mass tends to slowly move toward and into the opening.

\section{BACKGROUND}

Previous subsidence predictions for the WIPP site have been presented in published reports (DOE, 1980, 1990; SNL/NM, 1991). These predictions were based on various methods and present a range of maximum subsidence values from 0.09 to $1.0 \mathrm{~m}$. Investigation of subsidence has been performed for potash and salt mining operations around the world (Bawden and Mottahed, 1986; Salas, 1979; Steed et al., 1985; Whittaker and Reddish, 1989). The previous subsidence investigations in bedded potash and salt were reviewed to assess the subsidence prediction methods used and the applicability of each method to bedded evaporites.

\section{SUBSIDENCE ANALYSIS}

The amount of vertical surface subsidence expected to occur over the WIPP underground facility was calculated using three different computer and noncomputer methods. A summary of the methods used and an analysis of their applicability to bedded evaporite deposits in southeast New Mexico are presented. The results of the subsidence prediction analyses for WIPP using these methods are also presented.

\subsection{Subsidence Prediction Methods}

This section presents calculational and computer modeling approaches performed to determine the surface subsidence over the WIPP underground facility. The influence function method estimates the amount of subsidence expected from the underground excavations. The National Coal Board (NCB) method (NCB, 1975) was also used for analysis of subsidence. A detailed description of the numerical modeling using the Fast Lagrangian Analysis of Continua (FLAC) code (Itasca, 1991) is also given.

4.1.1 Influence function method. The influence function method provides a profile of the expected shape of the subsidence trough and the lateral extent of influence on the surface subsidence. This method assumes that each point in an underground excavation has a circular region of influence on the surface subsidence around that point. Therefore, in an underground opening, neighboring extraction elements generate identical subsidence basins at the surface. By superimposing the influence of all extraction elements, it becomes possible to calculate the total subsidence of a given point at the surface. The limit angle determines the area of influence. The circle is centered on the surface and its radius is given by (Kratzsch, 1983):

$$
\mathrm{R}=\mathrm{H} \cot (\gamma)
$$

where $R$ is the radius of the influence area, $H$ is the depth of the excavation and $\gamma$ is the limit angle from the horizon. Within this influence area, the subsidence profile will gradually reach a maximum value, $S_{\max }$. The maximum expected subsidence is a function of the dimensions of the workings and therefore is directly proportional to the seam height and the extraction ratio:

$$
\mathrm{S}_{\max }=\mathbf{a} \mathrm{M}
$$


the Influence Function and NCB subsidence prediction methods for the stratigraphy associated with the WIPP site.

In order to verify the applicability of the method to the particular stratigraphy found near the WIPP site, the Influence Function and NCB methods were applied to one of the potash mines located near the WIPP site. Two profiles, representing two different areas of the potash mine and two different mining methods, were used to check the applicability of the methods to mining in the WIPP area.

The first profile, Profile A, represents a modified longwall mining operation. The depth of the underground workings is $305 \mathrm{~m}$, the panel width is $457 \mathrm{~m}$, the initial height of the opening was $2.13 \mathrm{~m}$ and the extraction ratio is 0.92 (Powers, 1993).

The second profile, Profile B, represents a room-andpillar configuration. The depth of the underground workings used in the calculations was $305 \mathrm{~m}$, the width was $945 \mathrm{~m}$, the initial height of the openings was 3.81 $m$ and the extraction ratio was 0.83 .

Assuming a limit angle of 60 degrees, the influence function circle for the underground workings of both profiles is calculated from equation (1) as:

$$
\mathrm{R}=(305 \mathrm{~m}) \cot \left(60^{\circ}\right)=176.1 \mathrm{~m}
$$

Using a computer-aided drawing system, the influence function circle was superimposed along the profile on a scaled layout of the underground excavation. The center of the influence function circle is placed on nodes along the two profile lines. For each of these nodes an influence factor is calculated. The influence factors were calculated for each node across the potash mine profiles and are plotted in Figure 3.

Field measurements of subsidence from the potash mine were used to compare the accuracy of the influence function method as applied to the potash mine stratigraphy. It is assumed that maximum subsidence was almost reached when the field data were taken. Figure 3 also presents the shape of the subsidence trough observed using the field measurements and provides a comparison with the predicted subsidence. The calculated subsidence along Profile A substantially differs from the actual field data by overestimating the amount of subsidence observed. However, this profile is located in the comer of the mined area, which could limit the amount of observed subsidence.

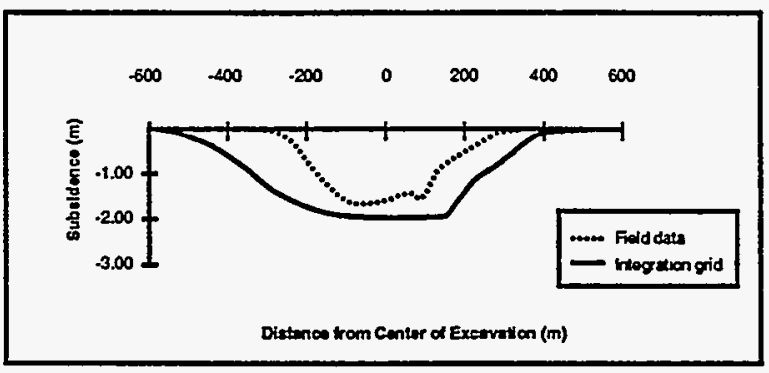

(a) Total Subsidence-Proflle A

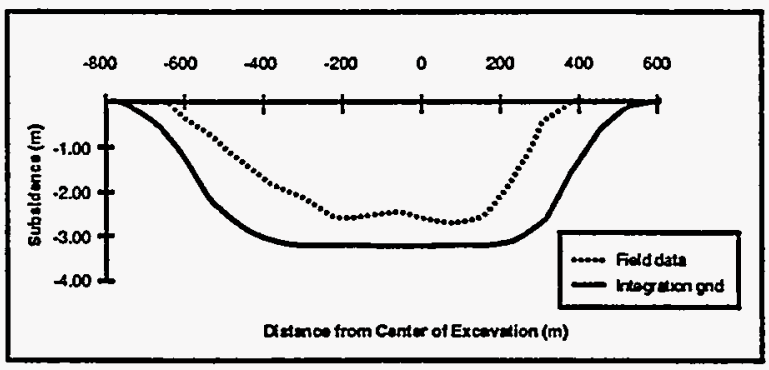

(b) Total Subsidenco-Protlie B

Figure 3

Comparison of Influence Function Method Results with Actual Field Measurements Across Potash Mine Profiles A and B

Profile B is in better agreement, with the maximum predicted subsidence $(3.16 \mathrm{~m})$ being slightly greater than the maximum observed surface subsidence $(2.80$ $\mathrm{m})$. The difference between observed and predicted surface subsidence may also indicate that subsidence activity is not yet complete. Because of the good agreement in subsidence profile and maximum subsidence between the influence function method and the field observations, the influence function method is expected to give reliable predictions of surface subsidence over the WIPP

The NCB method was then applied to the same two profiles. For the application of the NCB method, the area of pillars were ignored, and all of the underground workings were treated as a single panel. To do this, an "equivalent seam height" for the panel was calculated by multiplying the height of the opening by the extraction ratio yielding $1.96 \mathrm{~m}$ for Profile $\mathrm{A}$ and 3.16 $\mathrm{m}$ for Profile B.

For Profile A, the maximum subsidence was calculated by multiplying the equivalent seam height by the subsidence factor of 0.88 taken from a graph provided in the NCB Subsidence Engineers' Handbook (NCB, 1975). The subsidence factor was based on the depth 
where $S_{\max }$ is the maximum value of subsidence, $a$ is the extraction ratio, and $M$ is the height of the underground opening.

4.1.2 NCB method. The NCB method is an empirical method based on case histories of coal mining in the United Kingdom. The NCB developed an extensive program of scientific study and investigation of coal mining subsidence in the United Kingdom during the period from 1950 to 1965 (NCB, 1975). Field investigations were set up, and detailed measurements were made of subsidence, lateral displacement, ground strains, and tilt in many different mining and geological conditions. In addition, comparisons were made between British and German experiences, knowledge, and observations of mining subsidence.

The NCB empirical method consists essentially of a series of tables of data, charts, and graphs from which subsidence data can be derived and which relate to specific mining situations. Graphs are presented to provide correction factors for these specific mining conditions, such as length of the panel, pillar size between panels, and time since excavation. The general geological conditions are not considered as an individual parameter, since most of the observations related to similar overburden (Whittaker and Reddish, 1989).

4.1.3 FLAC modeling. FLAC is a finite difference code used to calculate stress, strain, and displacements around modeled excavations. It is used here to calculate the amount of subsidence at the surface. FLAC software has been used to develop numerical models of the underground excavations at the WIPP since 1991. FLAC is a two-dimensional explicit finite difference code that simulates the behavior of rock and soil-like structures. The WIPP Reference Creep Law (Krieg, 1984) is built into FLAC and has been verified to Nuclear Regulatory Commission standards (Itasca, 1988). FLAC is distributed by Itasca Consulting Group, Inc., of Minneapolis, Minnesota.

\subsection{Validation of the Methods Using Area Potash Mines}

Potash mining companies and their consultants performed the majority of the investigations of subsidence associated with potash mines in southeastern New Mexico. A summary of some of these reports and information received directly from the area potash mines is presented by Powers (1993). Subsidence observations from these WIPP area mines are extremely valuable for estimating the ground reaction and the amount and extent of surface subsidence to be expected over the WIPP underground.

Although the WIPP site is comparable to the potash mines in southeastern New Mexico, there are differences in stratigraphic position, depth, extraction ratio and layout. However, the overiying stratigraphic units are similar, as is the surface topography. The depth of the WIPP repository (approximately $650 \mathrm{~m}$ ) is greater than the depth of most of the area potash mines.

The extraction ratios within the potash mines are typically about 65 percent or greater with local extraction ratios approaching 97 percent in certain cases. The proposed WIPP extraction ratio is about 22 percent (SNL/NM, 1991), which is much lower than the area potash mines and should produce much less subsidence at the surface.

The potash mines of southeastern New Mexico have investigated ground-control problems in the upper Salado Formation for more than 60 years and surface subsidence for more than 40 years. The potash mines have used conventional room and pillar mining, secondary mining where old pillars are removed, and modified long-wall mining methods. Mining techniques used include drilling and blasting, as well as the use of continuous mining machines.

Large-volume underground mining commonly produces measurable surface subsidence. Within the Carlsbad Potash District, mines have demonstrably caused surface subsidence, resulting in fractures at the surface, ponding, road- and railroad-grade subsidence, and other effects. The principal mine subsidence data consist of networks of surface leveling baselines. In 1977, the National Geodetic Survey (NGS) established a baseline over large areas of southeastern New Mexico, including the WIPP site and some potash mines. A re-survey by NGS in 1981 revealed broad changes in elevation. The mine baseline and networks show much larger and rapid response due to high extraction ratios. Surface subsidence over a panel that has undergone secondary mining can begin within days to weeks and can be generally complete within about two years. Tension within surface rocks, as well as more readily observed subsidence, occurs within an angle of draw of about 35 degrees (measured from the vertical).

No local mine identically compares to the WIPP, but the subsidence data collected from area potash mines provide some insight into the expected surface subsidence conditions at the WIPP. The potash mine data were used in this study as a benchmark to validate 
and width of the mined panel. The maximum subsidence calculated was $1.72 \mathrm{~m}$ and the shape of the subsidence profile was predicted using factors provided by the NCB (NCB, 1975).

For Profile B, the subsidence factor was 0.95 because of the greater width of the excavation. The maximum surface subsidence was estimated to be $3.00 \mathrm{~m}$. The predicted and actual subsidence profiles for both Profile $A$ and $B$ are presented in Figure 4.

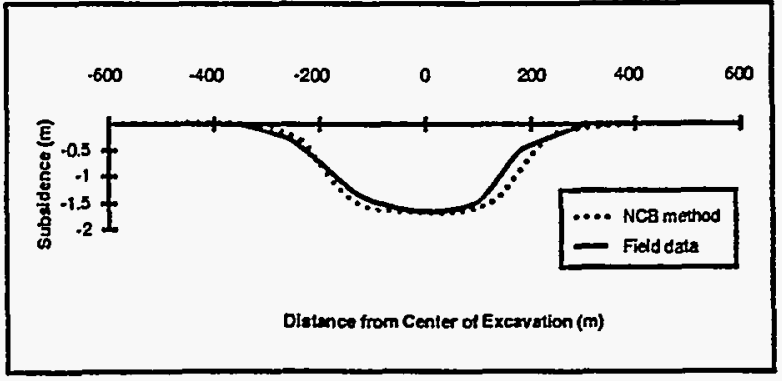

(a) Total Expeeted Subsidence-Profile A

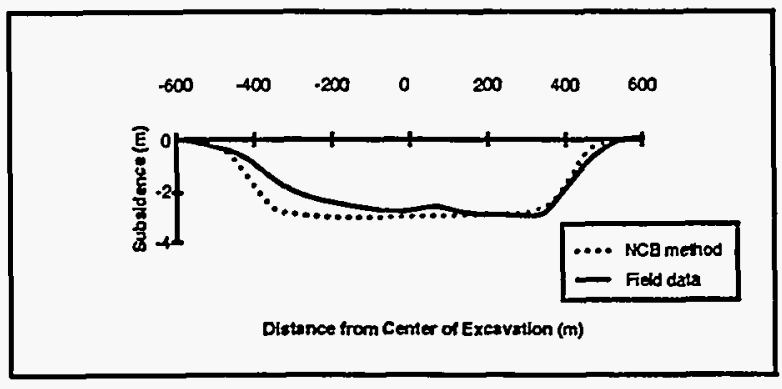

(b) Total Expected Subsidence-Profile B

Figure 4

Comparison of NCB Method Results with Actual Field Measurements Across Potash Mine Profiles A and B

Based on the results of this comparison, the NCB method appears to be a suitable tool for estimating total surface subsidence at excavations with high extraction ratios in the stratigraphy near the WIPP site.

\subsection{Subsidence Prediction at WIPP}

After validating the two subsidence prediction methods, they were applied to the WIPP site along with the FLAC model. The results are presented below.

4.3.1 Influence function method results. The graphical influence function method was applied to the WIPP site underground layout. Using a depth of $650 \mathrm{~m}$ and a limit angle of 60 degrees in equation (1), the radius of the influence circle is calculated to be $372 \mathrm{~m}$. Again using computer-aided design software, the influence circle was placed over each of the difference nodes of a regular grid overlaying a scale drawing of the WIPP underground. The influence factor was calculated for each node of the grid. Multiplying the influence factors by the maximum expected subsidence, a layout of the expected subsidence is obtained. Figure 5 presents the predicted subsidence contours for the WIPP. The maximum expected subsidence in the WIPP underground would be in the waste emplacement area and is predicted to be $0.56 \mathrm{~m}$ if the rooms are empty and $0.40 \mathrm{~m}$ if the rooms are filled with TRU waste.

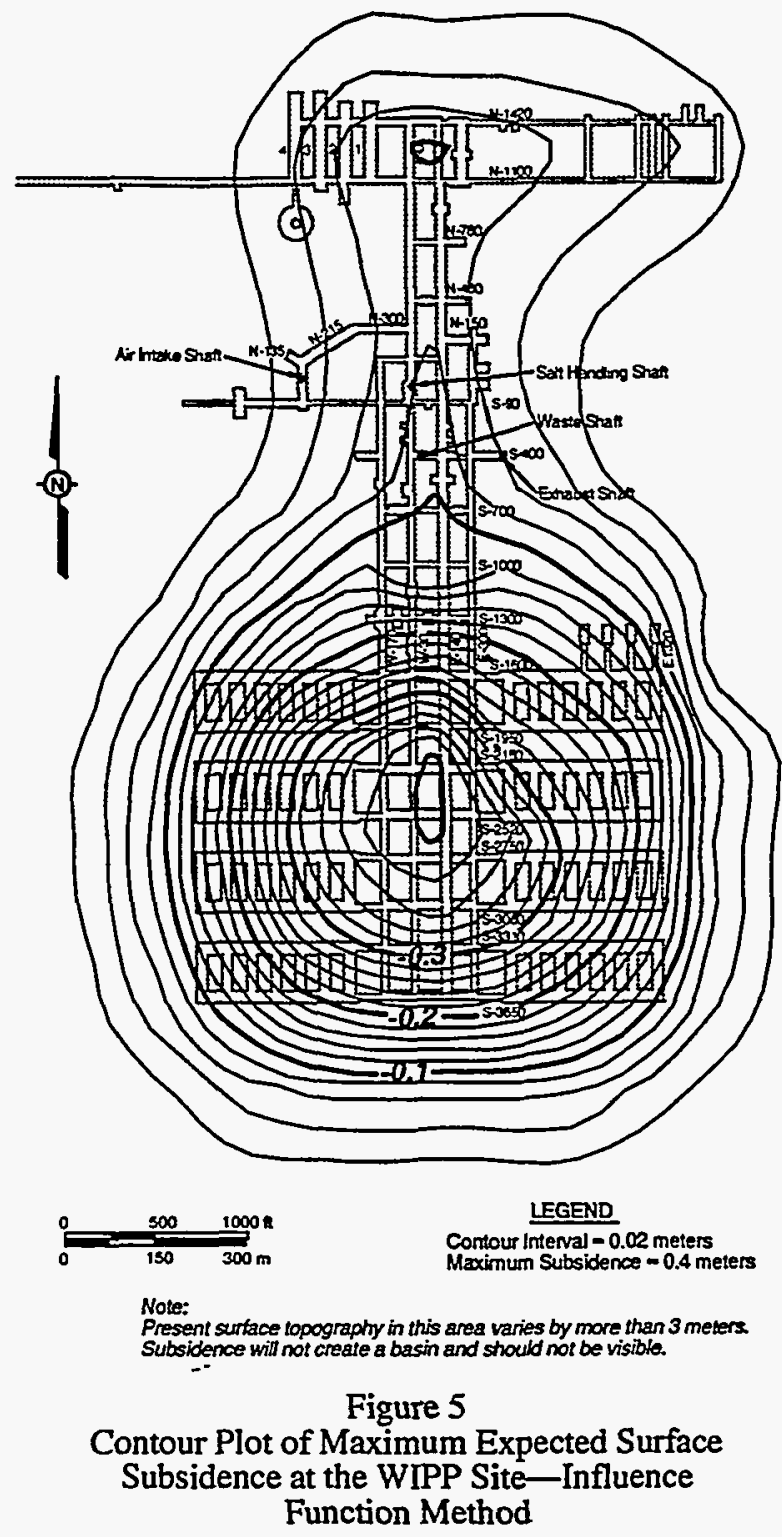

4.3.2 NCB method results. The NCB method was applied to the WIPP underground. The subsidence basin shape and magnitude for the entire facility were calculated by superposition. Figure 6 shows the 


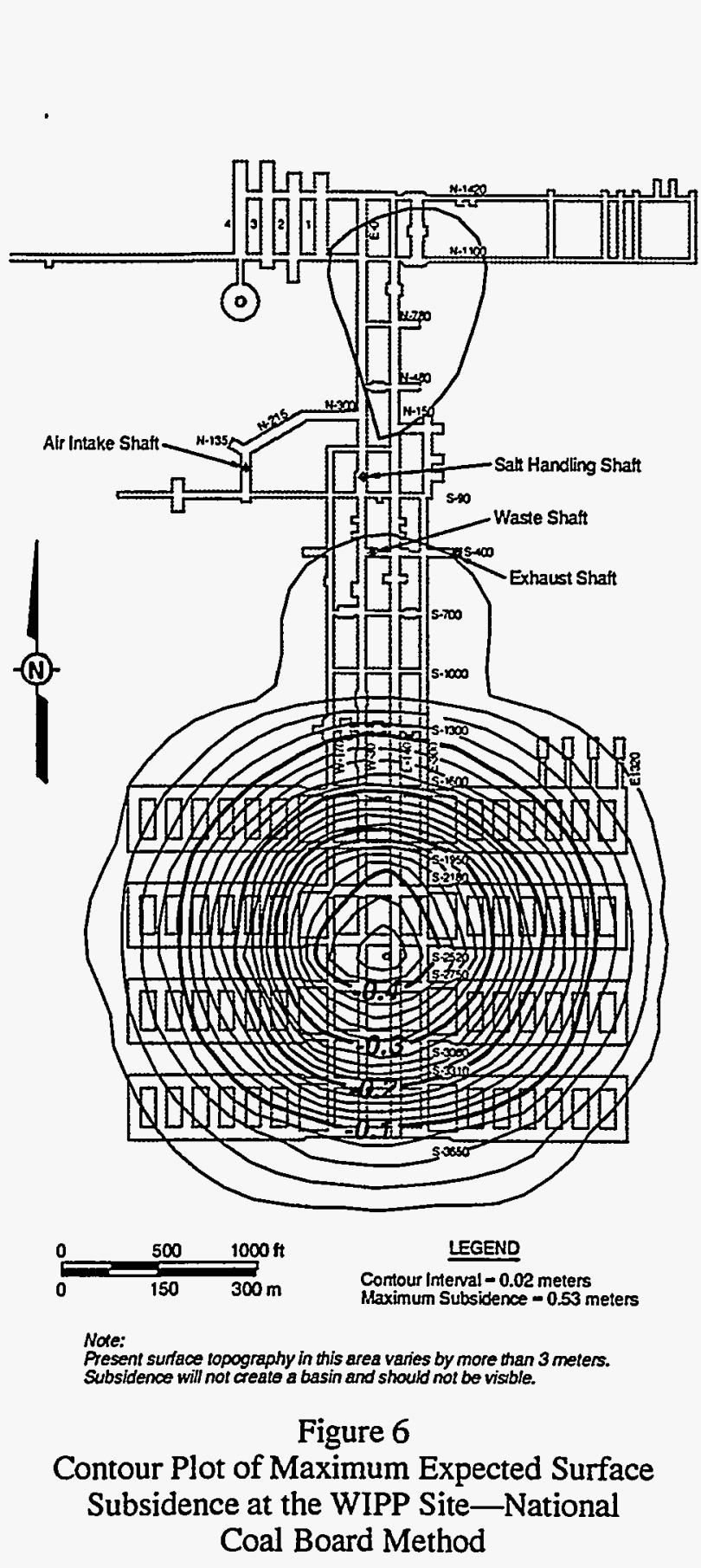

subsidence contour at the surface. The NCB analysis of the WIPP site reveals that maximum expected subsidence would occur over the waste emplacement area. The maximum expected subsidence in this area is $0.73 \mathrm{~m}$ assuming the area is empty and $0.53 \mathrm{~m}$ assuming the area is filled with TRU waste.

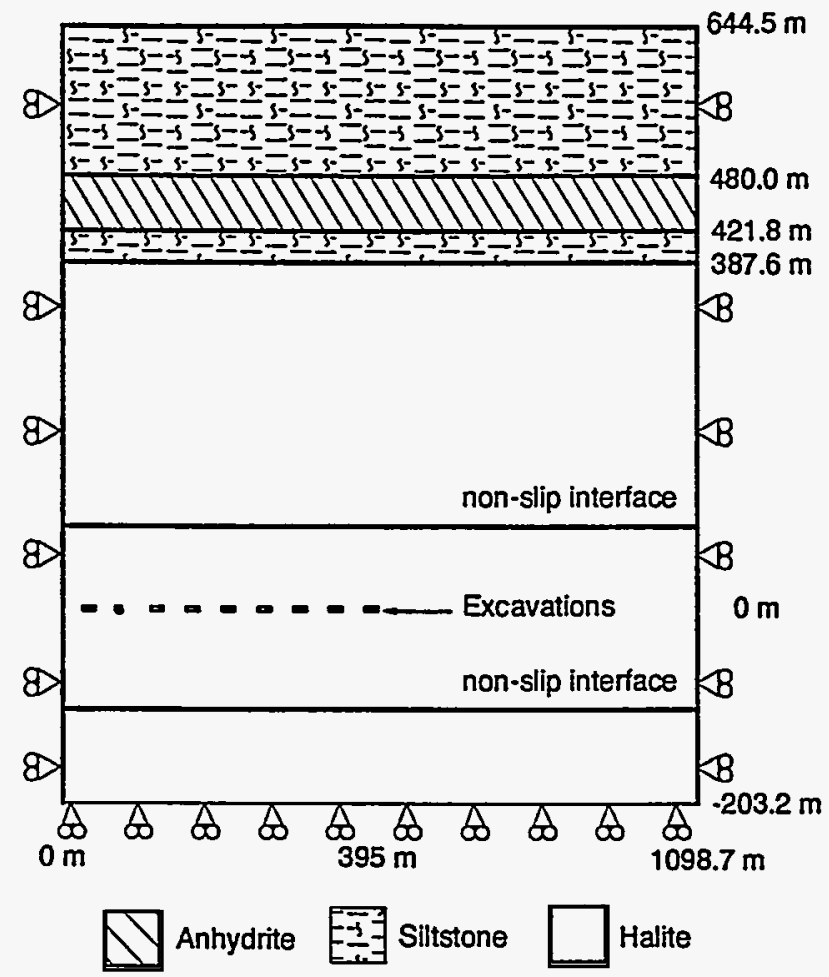

Figure 7

Subsidence Model Boundary Conditions and Stratigraphy

4.3.3 FLAC modeling results. A FLAC model containing two disposal panels and four access drifts (half by symmetry), was used to determine the curvature and depth of the subsidence trough. Figure 7 shows the boundary conditions and stratigraphy used in the model. The upper boundary of the model simulated the ground surface and was $644 \mathrm{~m}$ above the excavations. The lower boundary was $203 \mathrm{~m}$ below the excavations. The right boundary was about $740 \mathrm{~m}$ away from the right-most excavation. Boundary locations were selected so as to capture the shape of the subsidence trough.

The FLAC model was run to 380 model years. At that point, the maximum vertical subsidence was $0.48 \mathrm{~m}$. The subsidence rate was about 0.4 millimeter per year. At 380 model years, the remaining volume of the excavations was about 12 percent of the original. An estimation of the final subsidence that would have been achieved was made by dividing the 380 model-year subsidence results by 0.88 , giving a final maximum vertical subsidence value of $0.55 \mathrm{~m}$. Table 1 summarizes the results of the model. Results are shown for the conditions at the ground surface, at the Culebra Dolomite level, and at a position $335 \mathrm{~m}$ from the edge 


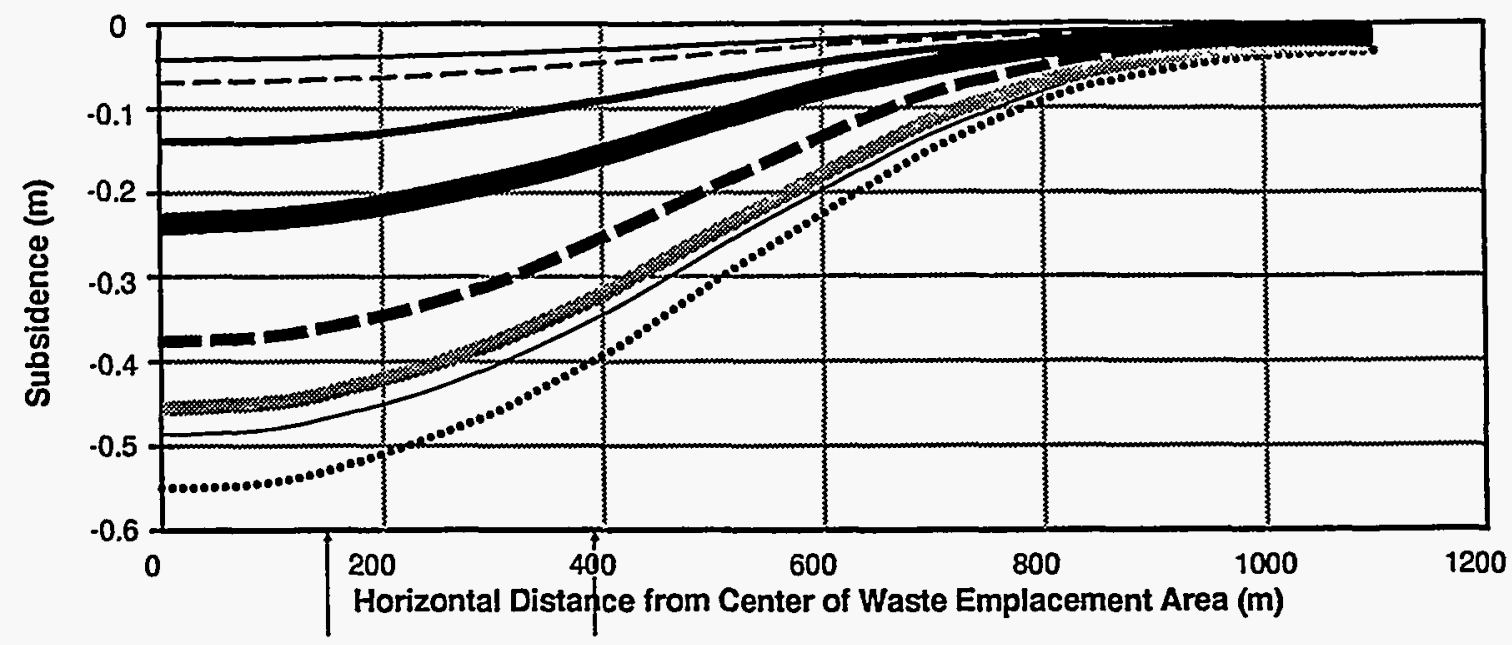

Room $1 \quad$ Room 7

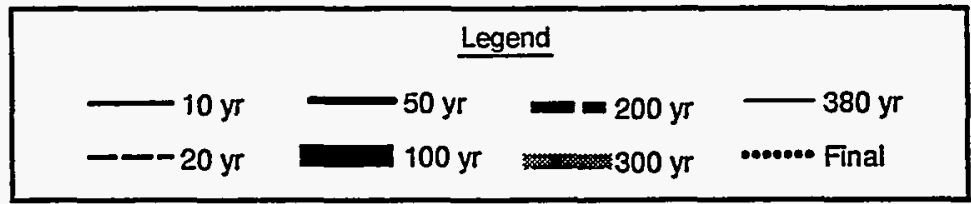

Figure 8

Subsidence Profile at Surface-FLAC Model

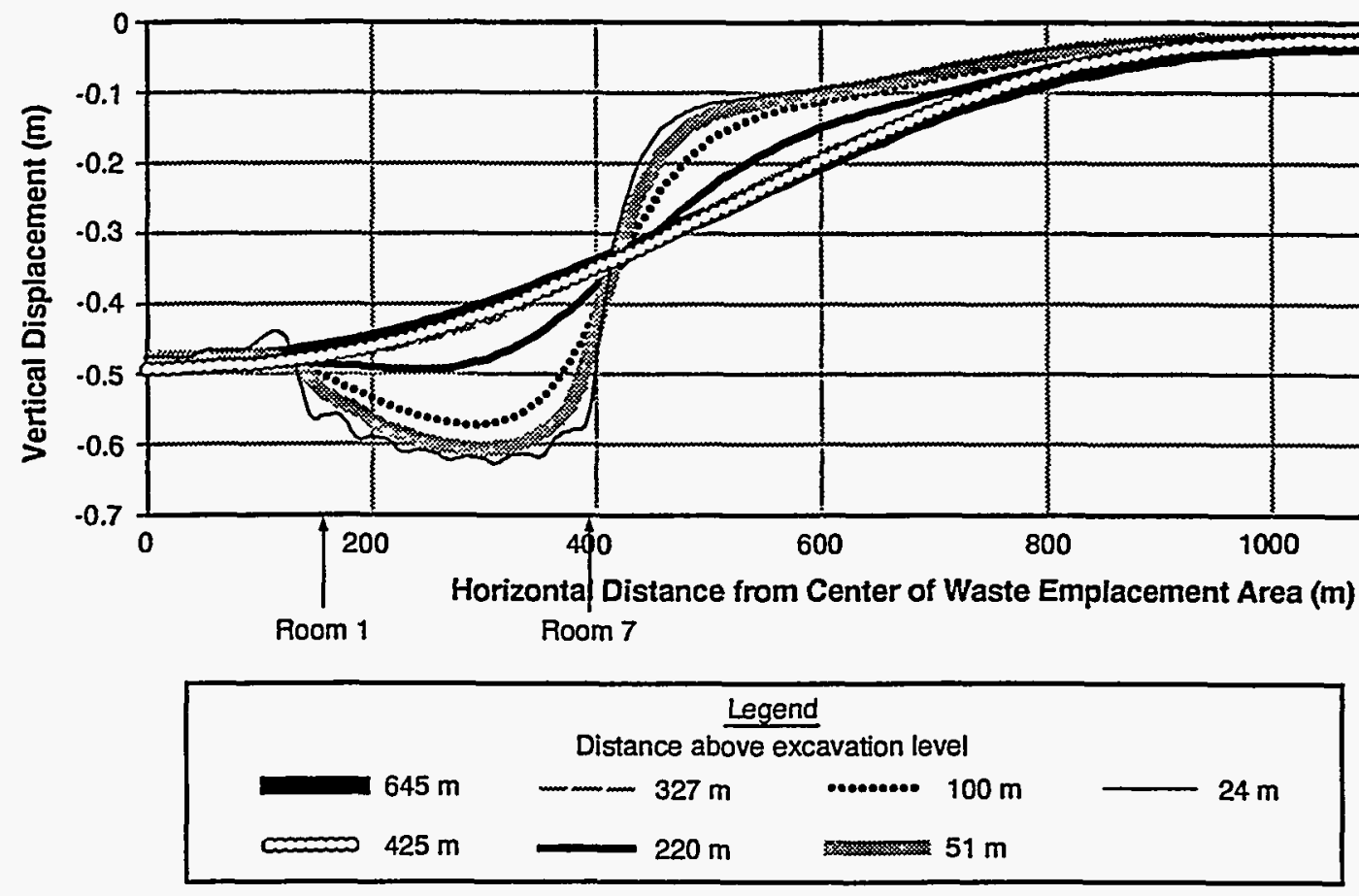

Figure 9

Subsidence Profiles at Various Depths-FLAC Model 
TABLE 1 Summary of FLAC Full-Panel Model Results

\begin{tabular}{||l|c|c||}
\hline \multicolumn{1}{|c|}{ Measurements at the Surface } & Value & $\begin{array}{c}\text { Distance from the Center of } \\
\text { the Waste Emplacement Area }\end{array}$ \\
\hline \hline Maximum horizontal displacement (at 50 yrs) & $4.4 \mathrm{~cm}$ & $501 \mathrm{~m}$ \\
\hline Maximum horizontal displacement (final) & $14.1 \mathrm{~cm}$ & $577 \mathrm{~m}$ \\
\hline Maximum vertical displacement (at 50 yrs) & $14.2 \mathrm{~cm}$ & $0 \mathrm{~m}$ \\
\hline Maximum vertical displacement (final) & $54.9 \mathrm{~cm}$ & $0 \mathrm{~m}$ \\
\hline Maximum compressive horizontal strain (at 50 yrs) & $-0.013 \%$ & $63 \mathrm{~m}$ \\
\hline Maximum compressive horizontal strain (final) & $-0.035 \%$ & $42 \mathrm{~m}$ \\
\hline Maximum tensile horizontal strain (at 50 yrs) & $0.011 \%$ & $697 \mathrm{~m}$ \\
\hline Maximum tensile horizontal strain (final) & $0.053 \%$ & $849 \mathrm{~m}$ \\
\hline Maximum trough slope (at 50 yrs) & $0.014 \mathrm{deg}$ & $418 \mathrm{~m}$ \\
\hline Maximum trough slope (final) & $0.048 \mathrm{deg}$ & $523 \mathrm{~m}$ \\
\hline
\end{tabular}

TABLE 2 Summary of Subsidence Prediction Results

\begin{tabular}{|c|c|c|c|c|}
\hline \multirow[b]{2}{*}{ Undeground Area } & \multirow[b]{2}{*}{$\begin{array}{l}\text { Contents of } \\
\text { Excavation }\end{array}$} & \multicolumn{3}{|c|}{ Subsidence } \\
\hline & & $\begin{array}{l}\text { Influence Function } \\
\text { Method (m) }\end{array}$ & $\begin{array}{l}\text { NCB Method } \\
\text { (m) }\end{array}$ & $\begin{array}{l}\text { FLAC Full-Panel } \\
\text { Model (m) }\end{array}$ \\
\hline \multirow{2}{*}{$\begin{array}{l}\text { Waste emplacement } \\
\text { area }^{2}\end{array}$} & Empty & 0.56 & 0.73 & 0.55 \\
\hline & Waste only & 0.40 & 0.53 & N.A. \\
\hline Shaft pillar area & Empty & 0.10 & 0.04 & $0.13^{b}$ \\
\hline $\begin{array}{l}\text { Northem } \\
\text { experimental area }\end{array}$ & Empty & 0.08 & 0.02 & N.A. \\
\hline
\end{tabular}

- Waste emplacement area includes Panel 1 through $8 ; 2$ through 8 are not yet excavated

${ }^{b}$ At the Waste Shaft 
of the panel, which is the distance of the waste shaft from the waste emplacement area. The 50-model-year and the estimated final values are given for all locations.

Figure 8 shows the shape of the surface subsidence trough at various times. Figure 9 shows the variation in shape of the subsidence trough with depth.

\section{SUMMARY AND CONCLUSIONS}

Each of the different methods used in the assessment were verified separately for use with the WIPP site stratigraphy. The influence function and NCB methods were validated against two case histories of potash mines in the vicinity of WIPP and found to be suitable for estimating total surface subsidence in bedded evaporite deposits in southeastern New Mexico. Despite the fact that the different methods are based on very different principles, all of the prediction methods yielded comparable results (Table 2). The maximum subsidence was obtained for the case of empty panels at the waste storage area. The magnitude of subsidence over the WIPP facility predicted by these analyses is not expected to significantly affect repository operations.

Work sponsored by the U.S. Department of Energy under DOE contract No. DE-AC04-86AL31950.

\section{REFERENCES}

BAWDEN, W.F., and MOTTAHED, P., 1986. Comparison of three subsidence prediction techniques applied to Saskatchewan potash mining. Proceedings, 88th Annual Meeting of C.I.M., Montreal. Paper No. 89.

ITASCA CONSULTING GROUP, INC., 1988. Thermal-mechanical benchmark testing of FLAC. NRC-02-05-002, prepared for the U.S. Nuclear Regulatory Commission, Division of Waste Management, Minneapolis.

ITASCA CONSULTING GROUP, INC., 1991. FLAC user's manual. Minneapolis.

KRATZSCH, H., 1983. Mining subsidence engineering. SpringerVerlag. New York.
KRIEG, R.D., 1984.

Reference stratigraphy and rock properties for the Waste Isolation Pilot Plant. SAND83-1908, Sandia National Laboratories, Albuquerque.

NATIONAL COAL BOARD (NCB), 1975.

Subsidence engineer's handbook. National Coal Board, London.

POWERS, D.W., 1993.

Background report on subsidence studies for the potash mines and WIPP site area, southeastern New Mexico. IT Corporation. Internal Distribution. Albuquerque.

SALAS, J.A.J., 1979.

Two subsidence cases in Spain. Proceedings, International Society of Rock Mechanics 4th International Congress on Rock Mechanics, Montreal, Vol. 3, pp. 369-373.

\section{SANDIA NATIONAL LABORATORIES/NEW} MEXICO (SNL/NM), 1991.

WIPP Performance Assessment Division (WPAD), preliminary comparison with 40 CFR part 191, subpart B for the Waste Isolation Pilot Plant, December 1991. SAND91-0893. Vol 1: Methodology \& Results. Sandia National Laboratories, Albuquerque.

STEED, C., BAWDEN, W.F., COODE, A.M. and MOTTAHED, P., 1985. Subsidence prediction for Saskatchewan potash mines. Proceedings, 26th U.S. Symposium on Rock Mechanics, Rapid City. Ed. E. Ashworth, A.A. Balkema, Boston.

U.S. DEPARTMENT OF ENERGY (DOE), 1990. Final safety analysis report (FSAR), Waste Isolation Pilot Plant. WP 02-9, Rev. 0, U.S. Department of Energy, Washington, D.C.

U.S. DEPARTMENT OF ENERGY (DOE), 1980. Final environmental impact statement (FEIS), Waste Isolation Pilot Plant. DOE/EIS-0026, U.S. Department of Energy, Washington, D.C.

WHITTAKER, B. N. and REDDISH, D.J., 1989. Subsidence: occurrence, prediction and control. Elsevier Science Publishing Co., Inc., New York. 